\title{
The Body Unbound: Ritual Scarification and Autobiographical forms in Wole Soyinka's Aké: The Years of Childhood
}

\author{
F. Fiona Moolla
}

The University of the Western Cape, South Africa

\begin{abstract}
The scarification in Aké is invested with major significance apropos Soyinka's ideas on African subjectivity. Scarification among the Yoruba is one of the rites of passage associated with personal development. Scarification literally and metaphorically "opens" the person up socially and cosmically. Personal formation and self-realization are enabled by the Yoruba social code brought into being by its mythology. The meaning of the scarification incident in Aké is profoundly different. Determined by the form of autobiography which creates a selfconstituting subject, the enabling Yoruba socio-cultural context is elided. The story of Soyinka's personal development is allegorical of the story of the development of the modern African subject. For Soyinka, the African subject is a rational subject whose constitution precludes the splitting of the scientific and spiritual which is a consequence of the Cartesian rupture. The African subject should be open to other subjects and the object world.
\end{abstract}

Subjectivity constituted by the autobiographical mode closes off the opening up symbolically signaled by scarification.

Keywords: Soyinka, autobiography, Bildungsroman, rites of passage, the subject, modernity

The most profoundly symbolic moment in Wole Soyinka's childhood autobiography, Aké, is the occasion when the young Wole receives from his paternal grandfather the arc-shaped slashes on his ankles and wrists which ritually and physically mark a stage in his development from childhood to adulthood. The significance of the incident is emphasized by the fact that it is referred to again in the adult memoir, Ibadan. The event acquires a charge also since it is a catalyst in the formation of Soyinka as artist. Scarification among the Yoruba, as will be shown, literally and metaphorically embodies the road in life's journey. Scarification, furthermore, is presided over by its tutelary deity, Ògún, the god of iron. Ògún for this reason is the patron deity of metalworkers and body artists, those who forge anew out of the smithy of creativity. Ritual scarification thus brings together in dynamic association Ògún and the road, out of which flows the idea of self-realization through artistic creativity. It might not be an exaggeration to suggest that in Soyinka's self-reflection, the incident of childhood scarification is the moment at which Soyinka, the artist, is inspired, or 'wrought'. Even more significantly, the formation of Soyinka as artist simultaneously embodies a conception of African subjectivity. In order to show the symbolic value of the incident of the scarification to Soyinka's ideas about the African subject, the genre of autobiography itself needs first to be considered. Autobiography as a life narrative needs to be explored to understand the nature of the self which the form constitutively assumes. 
Two recent overviews of postcolonial autobiography need to be considered here, namely, David Huddart's Postcolonial Theory and Autobiography (2008) and Bart Moore-Gilbert's Postcolonial Life-Writing (2009). Both works examine the ways in which postcolonial autobiographical forms challenge the sovereign, universal self identified with colonial modernity. Huddart's exploration foregrounds the centrality of autobiography, broadly defined, to the articulation of a postcolonial theory which, at its core, challenges conceptions of the self assumed by colonial modernity. Huddart points out that autobiographies or autobiographical reflections are associated with virtually all of the theorists of postcoloniality, among them, Frantz Fanon, Edward Said, Gayatri Spivak and Homi Bhabha. But Huddart makes the very astute observation that postcolonial autobiographical forms associated with these theorists simultaneously challenge the idea of the person in non-modern societies. Huddart suggests: "We might actually argue that the autobiographical transformation of postcolonial theory is concerned with transforming notions of universal subjectivity that themselves disrupt the possibility of community" (2008: 4). Although Soyinka is never associated with (and probably would not desire to be identified with) postcolonial theory, autobiography in Soyinka plays a similar role to that which Huddart identifies in postcolonial theory. Likewise, the tensions which emerge in Soyinka's reflections on, in this case, African subjectivity, are relevant to postcolonial autobiography generally. In fundamental ways, postcolonial theory remains bound up with colonial modernity in the automatic assumption of the concept of the self disengaged from a social code upon which reflections on the person are conceived. The idea of a self disengaged from a social code will be discussed fully in relation to Soyinka's childhood autobiography. However, the idea emerges clearly also in Moore-Gilbert's analysis of the ways in which postcolonial autobiography, or to use the preferred term in this work, life-writing, challenges the form of subjectivity associated with the colonial moment, but remains imbricated with it. Moore-Gilbert considers various examples of postcolonial life-writing from around the world. The life-writing he explores appears to challenge the centred, autonomous, sovereign self associated with colonial modernity. Moore-Gilbert finds an overlap in the strategies employed by these narratives of self with the strategies used by North Atlantic feminist life-writing. These strategies include various narrative techniques to decentre the centred self. Some postcolonial life-writing exposes the ways in which the independent, autonomous self is "relational" or, in other words, formed in relationships with others. Often postcolonial life-writing, Moore-Gilbert suggests, challenges the subject of colonial modernity through testing the generic boundaries of autobiography itself. In the case of Wole Soyinka's Aké, Moore-Gilbert finds that this autobiography confronts the idea of the universality of the modern subject through constructing a thoroughly located self, where "[t]he importance of place.. is foregrounded in the very title of [Soyinka's] text" (2009: 54), since Aké is also the name of the district where the author's childhood home is situated. However, Moore-Gilbert's analysis of postcolonial life-writing, like Huddart's exploration of the connections between postcolonial autobiography and theory, assume a disengaged self whose prior constitution is not put into question. Moore-Gilbert accepts the already individuated, free self presented in Soyinka's text. Referring to the way in which the young Wole shuttles between Christianity and paganism, Moore-Gilbert concludes that: "[c]onsequently Wole is not forced to ground himself within any singular cultural identity. Indeed, selecting as he pleases from each 
tradition, he also proves himself capable of rebellion against both" (2009: 57) The "Self" presented in the narrative thus suggests to Moore-Gilbert a subject fundamentally free to choose identity or identities at will. This is emphasised again when Moore-Gilbert considers the significance of locatedness and interconnectedness to this conception of the subject: "By choosing Aké for his title, Soyinka appears to wish to construct a relational Self...which recognises the determining influence on his formation not just of "place", but also of the community he grows up in." (2009: 57). What is taken for granted in both of these recent works on autobiography is the existence of a very particular kind of "Self", in fundamental ways a "free Self", which elusively occludes itself since it seems entirely natural. An interesting lack in both these works is the absence of attention to the ideas of the person constructed in various oratures and also various local literatures which might show up the ways in which the prior "Self", which is assumed, itself needs to be analyzed. An exploration of the significance of the scarification in Soyinka's childhood autobiography sheds light on the question suggested here.

Wole Soyinka's Aké occupies a special position among his autobiographical works as indeed autobiography stands among his prose writings. Within the ambit of a broad definition of autobiography, one may count four other works in Soyinka's oeuvre: the 1973 work, The Man Died (Prison Notes), İsarà: A Voyage Around "Essay" (1990), Ibadan: the Penkelemes Years: A Memoir 1946-1965 (1994) and the most recent publication You Must Set Forth at Dawn: A Memoir (2006). Soyinka makes a curious theoretical distinction between autobiography and novel through repeated assertions of an engaged interest in the former, with just a cursory nod in the direction of the latter. The distinction drawn and the preference attested are belied, however, by the author's practice. On more than one occasion in interviews, Soyinka denies an interest in writing or reading novels beyond a childhood predilection for Dickens (1992: 102). The author is far more open about writing autobiography. However, in these works too, with the exception of Aké, Soyinka cautiously emphasizes that there are external prods which encourage him to write life narratives, other than the personal need for self-reflection. According to the acknowledgements of You Must Set Forth at Dawn, these prompts include the need to capture erased histories in writing and the need to satisfy the interest of literary students and journalists in the details of his life (2007: n.p.).

However, having established a generic distinction between the novel, which is putatively fictional, and autobiography, which is commonly assumed to be factual, Soyinka begins, paradoxically, to break the distinction down. In the foreword to Ibadan, an autobiography in which the author figure is given the pseudonym "Maren", Soyinka suggests that the narrative "does not pretend to be anything but faction, that much abused genre which attempts to fictionalize facts and events, the proportion of fact to fiction being totally at the discretion of the author" (1994: ix) [emphasis in the original]. Soyinka borrows the portmanteau term "faction" from the new journalism of America in the late 1960s where the techniques of fiction were applied to reportage. By contrast, the conventions of journalism were applied to the novel in the context of the non-fiction novels of Truman Capote and Norman Mailer (Baldick, 2008: 124; Cuddon, 1999: 302). The concept of "faction," which describes a blend 
of fact and fiction at the author's discretion, aptly describes all of the autobiographical works and memoirs, with the exception of Aké, for which the author seems to claim a veracity beyond the poetic truth of fiction. With Aké, Soyinka appears to be asserting more than the frequently upheld idea that fiction refers to "lies which tell the truth". Instead, the author claims for this autobiography an ontic truth which derives from the fact that it constitutes a remembrance of childhood, which, for Soyinka, encompasses the years before the age of eleven: "Any testament after the 'age of innocence' is a lie, or half-truth, doctored truth, selective truth or annotated truth, or - in simple diction - a confection of sorts" (1994: x). On the question of Soyinka's rejection of the novel and embrace of autobiography, Biodun J eyifo's intuition may be the right one. J eyifo suggests that the elaborate distinction Soyinka draws between novel and autobiography is ultimately untenable in his writing practice; this distinction originates in the poor critical reception of, in particular, the second of Soyinka's two novels, Season of Anomy (2004: 169-170). To reiterate: Soyinka suggests a preference for autobiography over novel, but in the proposal that life writing is inherently fictional, breaks down the boundary between the two genres. Soyinka intimates, however, that the childhood self-recollections narrated in Aké capture an essential truth, which contradicts the trend towards the idea of the "constructedness" of reality presented elsewhere in his thought.

The boundary between novel and autobiography which Soyinka constructs and then, paradoxically, blurs, suggests an ambiguity which attends the eighteenth-century origins of both genres. The eighteenth-century novel originates in the ruse of the true account of a real life, as attested by Clarissa (1748-1749), Moll Flanders (1722) and Robinson Crusoe (1719) among others. Intimations of the subjectivity or fictional nature of the autobiography inhere in the paradox of its foundational premise: to give the completely veracious narrative of the life would be to present the life itself. The re-presentation of the life thus is inherently and inescapably fictional. Indeed, the constitutive impulse of both the autobiography and the Bildungsroman, that sub-genre of the novel which seems to define the novel itself, is the representation of the life which develops out of its own internal resources, what J oe Slaughter refers to as the Bildungsroman's "complex of inherency in becoming" (2006: 1415). In this respect, Aké is framed, scripted and determined by the naturalizing and naturalized assumptions of the Bildungsroman even as, in some ways, it appears to challenge these assumptions.

The template of the classical realist Bildungsroman is structured around the figure of the precocious small town youth at odds (as a consequence of too much "unsupervised reading") with family, in particular the father, and society. Education takes the hero from country to city, a journey both literal and metaphorical, where, after failed romance, the hero ultimately finds both life partner and station in society enabling social accommodation and a return home (Buckley, 1974: 17-18). The art of the novel of development allows the hero to assume a social role apparently entirely the product of his own volition and experience in the world. This development in the realist Bildungsroman is presented in linear time and is paradoxically teleological since the origins and trajectory of the life must subtly but clearly foreshadow its conclusion. In other words, the novel of development needs to construct a world within which the character's decisions and actions have a logical inevitability which 
derive from their internal consistency. The dynamic which drives the narrative is horizontal. Vertical intervention in the form of the shaping and foreclosing idea of providence or fate, or a sense of predetermination governed by the ideal of custom or tradition, collapses the epistemological assumption upon which this narrative form is based.

Aké assumes the pattern of the classical novel of development with a few key differences. Given the cultural provenance of this autobiography, one assumes that the destabilization of the unitary and disengaged worldview of the narrator would derive from the Yoruba culture for which the author has been an enthusiastic spokesman. The foregrounding of the individual, which is the hallmark of the autobiography, is definitive also, with some qualification, in Yoruba cultural forms. Clear illustration of the significance of the person in Yoruba culture is indicated, for example, by the related discursive practices of oríki and ìtàn chants (Yai, 1994: 107-108). Both oríkì and ìtàn are recitations, like biography and autobiography, which reflect on the lives of singular persons. What distinguishes itàn from oríkì, however, is the historical dimension of the ìtàn chant. J ohn Pemberton III defines the ìàn oral histories as follows:

Such histories recall the ancestral founder of the household, refer to the town or region from which the ancestor came with his followers, indicating (often cryptically) reasons for their departure, the vicissitudes of their journey, and the welcome they received upon arriving in the present location due to the particular skills or heroic deeds of the ancestor. . Above all else, the itàn remembers those men and women who brought fame to the family. (1994: 120)

Like the literary forms which foreground the life of the individual, the Yoruba oral history individuates, traces development as a journey through life and celebrates the final reincorporation of the person.

The oríki chants, however, more clearly indicate the fundamental difference between the Yoruba forms of reflection on the individual life and the autobiography/Bildungsroman. Karin Barber's research on the oríkì is the most extensive and detailed. Barber defines oríkì as "a genre of Yoruba oral poetry that could be described as attributions or appellations: collections of epithets, pithy or elaborated, which are addressed to a subject" (1991: 1). Barber eschews the common definition of oríkì as "praise poetry" since the oríkì operate more as "verbal salutes" (1994: 151), identifying what is unique and essential about the subject rather than paying tribute only to the person's positive qualities. Oríki thus also sometimes insult or embarrass their subjects. Performance of oríki requires some training, but is open to anyone with the verbal and imaginative talent. Oríkì, like written biographies, foreground the life of exceptional people.

A special form of oríkì is associated with wedding ceremonies. Unlike other forms of oríkì chants, the verbal salute of the bride is self-reflexive. In this respect it may be associated with the written autobiography. The oríkì of the bride is referred to as "rara iyawo". Barber defines the subject of rara iyawo as follows:

Everything the bride says in rara iyawo is intended to direct attention back to herself. The genre, in fact, is a long reflection on, and dramatization of, the bride's change of 
status. It asks the audience to look at her, observe her glory, recognize the transition she is undertaking. The verses [are].. invitations to the onlooker to acknowledge that this particular girl is at this moment embarking on married life.. Her performance is thus self-reflexive, a dramatization of the actual moment at which she is the centre of attention...The oriki circles back to the bride and becomes a reflection on her state. (1991: 113-115) [emphasis in original]

The representational impulse of both rara iyawo and the autobiography are similar; namely, the discursive construction of the narrator's life. What Aké seems to share in common with rara iyawo, furthermore, is the fact that both this autobiography and the oral genre appear to open the reflection of the self up to dimensions outside of the limits of comprehension of a realist worldview, where realism refers to the epistemological transformation associated with the Cartesian break. The narrating subject in Aké presents itself as "boundariless" in much the same way that the subject of rara iyawo and oríki generally are constituted as "open" selves. In both the text under consideration and the oral forms, time is not teleological. Instead, the past is shown to be immanent in the present and the present in the past. Likewise, superficially, both the oral and script forms of self-reflection appear open to a spiritual dimension. Oríki, generally, are considered to be "living link[s] through which relationships with the orisa, the 'gods', are conducted" (Barber, 1991: 4). Thus, superficially, the autobiography seems to reflect in script the worldview inherent in Yoruba oral forms.

However, rara iyawo and oríki, broadly, are profoundly different in their constitutive formation compared with Aké. The Yoruba verbal salutes exalt the person in the context of the person's lineage. As Barber suggests, "[t]hey provide a way of thinking about social relationships within and between families" (1991: 4). While kinship (both nuclear and extended) is a significant dimension of Soyinka's autobiography, the narrator is not constituted as a person organically out of these relationships. Instead, the narrator autonomously defines himself in relation to family and forebears. By contrast, lineage in oríkì and itàn is not part of a self-reflexive project. Barber emphasizes that in this context, "[i]ndividual identity is constituted out of communal identity: and at the same time it is through the salutation of the individual that group identity is reaffirmed" (1991: 250). The verbal forms reflect on status in the context of the system within which status is constituted. Oríki and ìtàn do not present a subjectivity which assumes the possibility of a worldview somehow outside of the system which constitutes it in the first place.

Thus, what makes the assumptions of the oríkì and ìtàn different from the fundamental assumption of Soyinka's childhood autobiography, is that the oríki and ìtàn are significantly "institutionalized". They represent a socially recognized "script" in a drama which creates self-reflexive persons through inescapable recognition of the common horizon within which each one is empowered. In terms of this common horizon, the bride who moves through the town reciting the rara iyawo chant makes her own unique journey in life, but she does not regard herself as mistress of her own destiny. She is not free in her self-construction to determine, for example, that she will reject the convention and expect it of her future husband instead. The bride is not at liberty as an individual to fashion her own "convention," 
since the existing practice arises out of a conception of an ideal code for women and for men, reflecting an idea of a natural order for which Yoruba mythology is the immediate apprehension.

But this does not mean that Yoruba culture is static. What it means is that meaningful changes are adaptations to transformed contexts, which engage both the cultural ideal and the shifting circumstance. Such transformations enjoy a thoroughgoing consistency in which individual and collective are not present as a dichotomy. While not entirely inconceivable in the contemporary context, the bride expecting the convention of rara iyawo from her husband-to-be would be considered ludicrous: this absurdity highlights the code which constitutes the Yoruba ideal. With the autobiography, as will be shown, the horizon held in common is lost, or rather, more correctly, sublimated, since the narrator of the autobiography is presented as a self-engendering and self-determining subject. Aké thus dramatizes the production of Soyinka's ideal African subject, theoretically defined in the lectures published as The Blackman and the Veil. In these lectures Soyinka presents as integral to black subjectivity the "right to self-regulation, self-direction and the production of [its] own future.. a simple task of self-redefinition" (1993: 7). In this assertion, Soyinka accepts both the conception of self as individual and the racial category of blackness constituted by the "other" world, which it is the object of the lectures to challenge.

I now wish to return to the question of what makes Aké unusual in the context of the classic novel of development generally and African life narratives specifically. With regard to the relationship between autobiography and Bildungsroman Apollo Amoko suggests, using Aké as an illustrative text, that in the "African context" there are "considerable correspondences and convergences" between the two genres. Furthermore, he argues that "Autobiographies and Bildungsromane participate in the same conversation regarding the fundamental nature of African societies in the wake of the encounter with colonialism" (2009: 195-196). For Biodun J eyifo, by contrast, Aké is "not a conventional Bildungsroman," since "it is not a story of growing up through an embittering loss of innocence or of a traumatic shedding of illusions through a very painful experience" (2004: 192-193). What is suggested here, by contrast, is that it is precisely because of the pressures of writing an African autobiography that this distinctive feature of the Bildungsroman (namely, the "embittering loss of innocence" or "traumatic shedding of illusions") is elided in Soyinka's text. The author's note to one of Soyinka's most well-known plays, Death and the King's Horseman, makes it clear that Soyinka identifies the "Colonial Factor" as "an incident, a catalytic incident merely" in the entry into modernity (Soyinka, 2002b n.p.). Soyinka's broad project, as will be argued in more detail momentarily, is to present modern identity as universal and, furthermore, to demonstrate the authentic African origin of modern subjectivity, which constitutively precludes the Cartesian rupture of poetic or spiritual modes from scientific ones. Kwame Anthony Appiah's critique that Soyinka projects the Yoruba mythopoetic part for the African whole is noted on the question of a recuperation of poetic or spiritual modes of perception. (1992: 79-82). Noted also is the observation that the idea of an "Africa" with a unique spiritual identity itself is a response to modern forms of both colonialism and slavery. The art in Aké, like the art of the novel of formation, consists in presenting this project entirely 
naturally, emerging purely out of the observation and rational ordering of experience of the developing child.

The selection of childhood incidents narrated in Aké presents a preternaturally intelligent child who at the age of two strategizes his own admission to the school at which his father is the headmaster. The text abounds in references to the young Wole who is an insatiable reader, an addiction from which the family repeatedly try to save him, inculcating instead the lessons of real life. While not exaggerating the differences between himself, his father and the members of the extended family and friends, the autobiography presents its subject as egregious in various ways. He attempts to avoid the menial household chores and considers it an affront to his dignity to be forced out of his privileged position in the patriarchal bed onto the communal mat on the floor. He plots an escape "from a household whose subtle hostilities had begun to prickle [his] skin" after, to his mind, irrationally being reprimanded for the theft of powdered milk which was not being used anyway (1981: 92). Unlike the classic realist novel of formation, romantic attachments do not appear significant to self-realization either in Aké or in any of the other autobiographies and marriage is not a defining horizon. There is also no staged linear development progressing to self-fulfillment and social accommodation in closure. Instead, the narrative adopts the techniques of modernism, which disrupt linear time and, through stream of consciousness, presents a consciously subjective and in some ways metatextual narrative. The text might be termed episodic if it were not for the subjective connections among incidents. The narrative moves from time to time and space to space through subjective links. For example, the time sequence of the section of narrative describing the young Wole's conversation with the white officer in Ibara is broken for a long aside on the Hausa traders who visit the Aké parsonage simply because the accent of the Hausa sergeant present sets off a chain of reminiscences. Similarly the word "rafters" (referring to roof beams) shifts the narration from the father's house in Aké to the grandfather's house in Ísará following the fascination of the subjective consciousness with the materiality of the word. The first person narrative shifts from focalization through the child to focalization through the adult narrator, returning to the childhood scenes, simultaneously conflating times present and past. Like the orikì chants thus, the narrative shows the past in the present and the present in the past, but the framework within which it performs these moves is fundamentally transformed. In fact, one might say that the framework is internalized.

The motif of life as a journey is central to all paradigms of personal development and Aké is no exception. True to the impulse of the autobiography, where the subject is retrospectively shown to become whatever he all along was in any case, a childhood foray beyond the walls of the home is charged with hugely symbolic proleptic import. At the age of four and a half, the young Wole follows the police marching band from Aké to the next town, Ibara. This experience subliminally brings together all the elements key to Soyinka's self-definition. Associated with it are notions of rites of passage, where the narrator suggests he had "become markedly different from whatever [he] was before the march" (1981: 50). Also strongly suggested is the symbolism of the road, which is significant in Yoruba culture and in Soyinka's personal philosophy. The figure who holds all of these conceptions together is 
Soyinka's personal deity, Ògún, the god of iron, of circumcisers and of body artists (Drewal, 1997; Drewal and Mason, 1997) whose significance is signaled in the overt reference to the scarifications on the face of the Hausa policeman who comes to the young Wole's rescue when he finds himself far from home.

This journey in miniature is repeated and magnified when, at the age of eleven, the autobiographical narrator makes the journey of the Bildungsroman hero from the country town of Aké to Government College in the city of Ibadan. In this case, however, in what represents a departure from the classic novel of development, the move from country to city and the experiences the city allows do not bring accommodative closure. Instead, closure marks the beginning of another cycle of development: "It was time to commence the mental shifts for admittance to yet another irrational world of adults and their discipline" (1981: 230). Closure thus reinforces J eyifo's insight, noted above, since what is tracked is not the disillusionment of a transition from a prelapsarian state of innocence to a state of experience, but a continuing negotiation with the world from a subject position presented as natural, in the sense that it is outside of culture or ideology, from a subject position presented as universal, since it is self-constituting, rather than being formed within a particular, sociocultural matrix. In this respect, Aké is different from most other African autobiographies: there is no loss, exile, alienation. Thus within the broad frame of the pattern for individual formation offered by the realist Bildungsroman, Aké unsettles some formal expectations.

Aké, however, is fully inserted into the fundamental assumption of the autobiography/Bildungsroman: the assumption of a "disengaged" subjectivity which constructs, out of its apprehension of experience, a worldview. Since the autobiography/Bildungsroman enacts, in the sense of literally dramatizing, its foundational assumption of "procedural rationality", this form of subjectivity is also presented as transparent, "natural". The idea of a rationality which is procedural, where truth depends on how it is acquired, eliding the prior production of the thinking subject, rather than substantive, where the framework which enables the subject is acknowledged, is fully elaborated in the work of the Canadian philosopher, Charles Taylor (1989). The procedurally rational subject is a modern subject. What procedural rationality occludes is the substantively rational framework of mythological apprehensions of the world upon which it depends, but which it rejects. In other words, the procedurally rational subject, which is the subject represented in the narrative of Aké, cannot be formed outside of some substantively rational account of its coming into being. Substantive rationality constitutively assumes a collective and relatively certain view of the world determined by custom or tradition, in various ways among different cultures, mediated by the transcendental. The person is formed in such worldviews out of an obligation to an ideal for the most part held in common. But obligation in relation to substantively rational outlooks is not conceived as compulsion. Obligation emerges as compulsion only to the extent that a procedurally rational view is able to imagine itself outside of, and independent of an ideal held in common. As we shall see, Soyinka presents himself in the autobiography as unable to accede to the Yoruba social code. Paradoxically, for this reason, the value invested in the scarification, which is meant to open up the closed, procedurally rational subject, remains a token gesture merely. 
The procedurally rational assumption which shapes the formation of the subject in Aké, is clearly shown in the reading of the novel by Amy Beth Cross. Cross analyses Aké in the context of a number of other African works of fiction and non-fiction for what they reveal about the entry of African writers into institutions of higher education. Cross suggests that what makes Aké stand out from similar works is the fact that Soyinka presents himself as independently learning "what was important about learning and development" (1996: 24). One witnesses in the autobiography the young Wole self-reflexively "telling himself stories" (1996: 24). His learning emerges as entirely "relational" (1996: 24). It is learning "in which the environment speaks to him and he to it" (1996: 24). In other words, what Cross's analysis suggests but does not articulate, is that the development of the young Wole is presented as a procedurally rational self-reflexive project, within which the substantively rational social worldview, which is its prerequisite, is entirely elided.

Cross reiterates the observation of James Olney in his comprehensive study of African autobiography that "striving for education" (1973: 44) is a "controlling principle" (1973: 45) of African autobiography. Almost without exception, the entry into colonial education marks the separation from home. The passion of the young Wole for school is such that, as has been noted above, he plots his own entry to his father's school at the age of two and much of the latter half of the work describes the trials and tribulations of gaining admission and a scholarship to attend Government College, Ibadan. What the child Soyinka discovers at the schools he attends in Aké, Abeokuta and then Ibadan, is that educational regimes, and, in particular regimes of discipline, appear to defy his conception of logic. Cross suggests that what one witnesses in Aké is the reversal of the trope of alienation: "[r]ather than education alienating him from himself or his world, school has alienated itself from him" (1996: 26). What Cross means by this is that entering the colonial education system almost invariably in African Bildingsromane/ autobiographies results in the narrator becoming to a certain extent a stranger to the worldview which created her/ him. A case in point, though not one discussed by Cross, where this transformation is perfectly clear, is Tsitsi Dangarembga's novel, Nervous Conditions. In this novel of formation, the entry of the heroine into colonial education is described as a "reincarnation" (1988: 92). The newly formed subject constituted by a modern regime of personal development views the homestead from which she comes with the eyes of an outsider. She has been alienated. In Aké, by contrast, the reversal of the trope of alienation can occur precisely since Soyinka presents a subject who educates himself and through education constitutes himself. The social and mythological matrix against which the person necessarily and inescapably must be constituted has been hidden from view. Instead, the young Wole is presented as self-engendering. And this, it appears, is the founding principle of eighteenth-century European autobiography, as opposed to other forms of life narrative, both oral and verbal.

Roy Pascal, in one of the most well known surveys of autobiography, suggests that authentic autobiography reveals the truth of a life which develops naturally and organically through intense experiences which are peculiarly one's own. Autobiography concerns the discovery of spiritual identity of personality through a focus on the self sought in concrete experienced 
reality. With autobiography, this discovery is always retrospective; thus Pascal notes what he terms an "interplay, a collusion, between past and present" where the present must be felt to be anticipated by the past (1960: 11). This is territory comprehensively covered by Eldred Durosimi J ones in his overview of the autobiographical elements in Aké and does not need to be rehearsed here (1973: 23-37). More than just a Bildungsroman, Aké is a Künstlerroman, which indexes Soyinka's future artistic production in the experiences and inspiration of childhood.

Thus the central question addressed by Aké is the central question addressed by all other autobiographies - "How have I become what I am?" To answer this question, the narrating subject needs to be self-reflexively aware of itself. It needs to see itself as distinct from the world around it. The narrating subject needs to filter and analyze its experience of the outside world in terms of the procedural rationality of an inner sense-making mechanism. And it needs, finally, to reflect textually on this process. Aké performs all of these moves.

But Aké carries the weight of another responsibility also. Soyinka's autobiography needs to show that this modern identity, since a modern identity undoubtedly is what he presents, is the product of an autochthonous African worldview. This is where the claim that Aké represents an "age of innocence" is crucial, since it, unlike the other autobiographies, appears to stand outside of history, representing what Soyinka in Myth, Literature and the African World refers to as the "universal verities" (1976: xii). History, stricto sensu, is amply dramatized in the autobiography in, for example, the representation of the impact of World War II and anti-colonial resistance on Aké. But the childhood autobiography stands outside of history, as the author intuits in his frequent assertions of its special place in relation to his other autobiographies, in the sense that it engages in a distinctive kind of mythmaking which denies that it is mythological. The "myth" established by Aké is the African authenticity of the subject, whose epistemological and ultimately moral sources are internal to himself.

In this lies the achievement of Aké. The autobiography presents the emergence of the modern subject wholly out of African soil, but even more remarkably this is a modern African identity which seems to suture the divide of the binaries of the Enlightenment philosophies out of which European modernity originates. The opening paragraphs of the autobiography irrevocably link the life recounted to place, to the structures, natural and man-made, of Aké and simultaneously frame the locale within a Yoruba cosmogony, showing the "earth being" of the African, his "gravity-bound apprehension of self" within cosmic totality (1976: 3):

The sprawling, undulating terrain is all of Aké. More than mere loyalty to the personage [sic] gave birth to a puzzle, and a resentment, that God should choose to look down on his own pious station, the parsonage compound, from the profane heights of Itókò. There was of course the mystery of the Chief's stable with live horses near the crest of the hill, but beyond that, this dizzying road only sheered upwards from one noisy market to another, looking down across Ibàràpa and Ita Aké into the most secret recesses of the parsonage itself.

On a misty day, the steep rise towards Itoko would join the sky. If God did not actually live there, there was little doubt that he descended first on its crest, then took 
his one gigantic stride over those babbling markets - which dared to sell on Sundays into St Peter's church, afterwards visiting the parsonage for tea with the Canon. (1981: 1)

In this mischievously humorous sequence which undermines monotheistic cosmology, the Christian God descends upon Aké parsonage much as the pagan Yoruba gods descend upon earth, creating a more human-centred theology where "the passions of the deities are brought to a terrestrial level" (1976: 24). The conflation of Christianity and Yoruba paganism is extended a few pages later, where the representation of St Peter in the stained glass windows of the church is assumed to be an image of an egúngún, or ancestral spirit, in a Yoruba masquerade, since St Peter wears a robe like the egúngún's. Fluid boundaries between zones of reality are explored with childhood relations and friends who commune with various kinds of spirits and the child Wole himself is terrified by the ghost of a dead Bishop whose eyeballs drop into his pocket-watch.

Soyinka, in the ways described above, sets about constructing in Aké a body which, unlike the bodies constituted by Cartesian thought, is unbound. Taylor refers to the subjectivity which is constituted by an "open boundary," which is porous since it draws its source from an idea of truth located externally to itself (1989: 191). The body, unlimited by a procedurally rational worldview, enjoys a sympathetic relationship with the cosmos and is open to areas of experience which may not be verified in terms of the protocols of procedural rationalism. The rationality of the porous subject is, however, wholly verifiable within the protocols established by its enabling mythology. And mythology here is used not as "false story" but as constitutive story.

Likewise, the line between adult reason and childhood irrationality is repeatedly erased in the narrative, but most memorably in the culmination of the rite of passage incident, referred to above, where the young Wole takes his first unaccompanied journey away from home. The trope of the colonial encounter, familiar from the imperial adventure story, but perhaps perfectly symbolically contained in Crusoe's encounter with Friday, is ludicrously parodied in the encounter of the young Wole with the white police officer at the end of the parade of the police band. In the first place, the representative of colonial authority is assumed to be an albino, a freak of nature, since the child has never before seen a white man. The child notes that this uniformed official wears shoes, unlike the black policemen who go barefooted. Shoes are a repeated focus of speculation for the young Wole in the autobiography. The rules which circumscribe the wearing of shoes suggest that only adults are allowed to wear shoes. Thus, on account of his footwear the officer is assumed to be an adult. This assumption is undermined, however, by what the narrative presents as his ingratiating childishness. In a reversal of the protocols of the colonial encounter, the white officer addresses the child Soyinka (unlike Crusoe's primal exchange with Friday) not in a rudimentary English, but in a completely garbled Yoruba, which the four-and-a half-year-old child recognizes to be one of the languages he speaks, but whose meaning he, in this distortion of it, cannot discern. The child expresses his confusion in English. The rest of the interview proceeds in English, but it is an English which to the ears of the black child the white man does not seem able to 
articulate particularly well. It is also an exchange where the adult comes off rather poorly for behaving in a more childish way than the child, as suggested by the officer's response to the young child's request to go home. The officer replies fondly: "Well, that seems vum-vumvum." (1981: 46)

When asked his father's name, the child responds to his interlocutor's amusement that his father is known as "Headmaster" or by his other name "Essay". The police officer laughs at what he takes to be the defective reason of a child. But, of course, "defective reason" masks the animist rationality of the child, where the spirit resides in the thing. This materialist rationality operates with the concrete rather than the abstract. In this sense meaning is shown to be immanent in the thing itself rather than residing in an etherealised spirit. In terms of this thinking, one's name is what one is called. Since Wole's father is hailed as "Headmaster" by some, alluding to his profession, and as "Essay" by others, alluding to his initials, "S.A." standing in for "Samuel Ayodele", these are logically construed by the child to be his names. The logic which regards one's true name as one's baptismal name is not selfevident but bound by convention. Again, this is just one example in a narrative which provides many others of an alternate animist rationality. In this scene Soyinka deconstructs Enlightenment dichotomies without relapsing to the notion of the unified "childhood of the race" since the child in question is highly intelligent. Furthermore, the child's childhood "irrationality" exposes the conventional rather than self-evident nature of adult "rationality".

What Aké thus appears to achieve is the representation of a fully modern identity out of an authentically Yoruba worldview, where, as Appiah suggests, as noted above, "Yoruba" as a synecdoche is representative of the whole of Africa. The achievement of the autobiography may be contrasted with the project presented by Soyinka in another genre which also approaches its fully realized embodiment in the eighteenth century, namely the essays anthologized as Myth, Literature and the African World, in particular "The Fourth Stage". (The essay, like the autobiography and the novel, is a genre which, in the practice of its progenitor, Montaigne, evolved as a constitutive literary medium for reflection on the individual.) If Aké shows, one might say "empirically" given the technique of representation of the autobiography, the emergence of the African individual, "The Fourth Stage" by rational argument tells the formation of modern African identity embodied in the Yoruba god, Ògún, In the figure of Ògún Soyinka dramatizes the symbolic African individual, most often embodied in the artist. The Ògún/artist figure paradoxically, in his destructive-regenerative being, sutures the individual and the social severed in European modernity. The reconnection of the individual and the social occurs since Ògún's moment of individuation, in Soyinka's representation of it, unlike the individualism of European modernity, is communicant. This process occurs in the transitional abyss of the fourth space through the Ògún/artist figure's superhuman cosmic will. As will be suggested through the analysis of the role of ritual scarification in Aké, the idea of the "will" associated with Ògún comes closer to the status of "willing" in the nineteenth century German philosopher, Arthur Schopenhauer, than it does to the concept of the will in Yoruba practice.

Margaret Thompson Drewal prefaces an analysis of the embodied ritual initiation practices of a Yoruba diviner, Kolawole Ositola, with an observation about the self-reflection of Yoruba 
performers. Drewal observes that 'Yoruba performers regard themselves as 'people of action' [an] idea [which] inheres in a Yoruba theory of action termed àse." This, Drewal claims, "is one of those fundamental concepts like 'will' that philosophers write entire books about." Drewal adds that, "[Àse] is at a very fundamental level understood by Yoruba performers as 'the power to bring things into existence," or "the power to make things happen." (1994: 171) As will be shown in the analysis of the scarification in Soyinka's childhood autobiography, Yoruba "will" exists in an embodied social practice as a collective ideal. The will of which Ògún is the symbol in Soyinka's aesthetic comes closer to the concept of will in Schopenhauer, who engages and partially rejects both Kantian rationalism and German Idealism. For Soyinka, as in Schopenhauer, the will is identified with the instinctual rather than rational drives of the introspective individual which produce art as a moral ideal.

Underscoring the universality of the process of individuation, Soyinka stresses the continuities between the mythology of Grecian antiquity and contemporary Yoruba mythology. Ògún is, in part, the Yoruba counterpart of Prometheus and Dionysus. As Kwame Anthony Appiah notes, Soyinka's rewriting of Yoruba mythology is filtered not coincidentally through Greek mythology. Negritude, it is well known, comes off rather poorly in Soyinka's view. Regarding Negritude's appropriation of the idea of African "emotionalism" in response to the "rationalism" of colonial self-definition, Soyinka retorts that: "A tiger does not proclaim his tigritude, he pounces." (Jahn, 1966: 265) Negritude allows Africa to enter modernity through an embodied reinterpretation of the European concept of blackness forged out of the nineteenth-century science of race. Soyinka, by contrast, theorizes African entry into modernity through a Yoruba/ African mythos read through an Enlightenment reinvention of Hellenic mythology. Ato Quayson suggests that Soyinka

transfer[s] the myths from its [sic] ritual contexts of performance, but by the extensive interpretation to which he submits them, their original terms are re-written so as to embrace new aesthetic, cultural, and even political realities that were not within their purview in other cultural uses. (1997: 75)

The Yoruba metaphysics created out of this nexus, furthermore, as Ato Quayson notes, is a singular interpretation of the broad, accommodating and protean "church" of Yoruba tradition. In Ibadan the Soyinka figure, 'Maren', relates the profound moment when he comes across an old edition of William Blake's Poems, one book among many a teacher wanted to pass on to pupils rather than discard. Maren is fascinated by the poems, as he was by the teacher's exegesis in class of Blake's "Tiger":

He had listened to Mr Kayes's exposition of the poem with rapt interest and a little bafflement. As he read its companions in the volume, however, he felt somewhat more at home with the strange world of this possessed stranger, who appeared to share some of the theology of Aké, yet partook of the fantasy world of Fagunwa's Ogboju Oke Ninu Igbo Irunmale, or indeed Ireke Onibudo. It was again an echo of the sensations he obtained when he stared at the stained-glass window of St Peter's church at Aké where the haloed pictures of saints and founding missionaries of the church fused with the masked figures of egungun. (1994: 150-151)

The affinity with Blake is highly understandable. Like Blake, Soyinka constructs a personal mythology out of Yoruba cosmology. Donald Cosentino in "Repossession: Ògún in Folklore 
and Literature," explores the multiple ways in which Yoruba mythology, in particular the figure of Ògún, the god of iron, war and hunting, has entered the contemporary cultures of West Africa and the West African diaspora. Cosentino observes that Soyinka has created a "personal Ogún" that "exists on at least three permeable levels: the personal, the critical, and the artistic" (1997: 305). The figure of Ògún here acts as a metonym for Yoruba mythology broadly. What is noticeably absent in Cosentino's assessment of the use of mythology by Soyinka, is any sense of Ògún binding the artist to an ideal held in common through a collective practice.

What the analysis of Aké, drawing on its similarity to the Bildungsroman, and the project of the essays suggest, is that far from demonstrating the entry of the African subject into modernity from an autochthonous African soil, the identity suggested at the outset is a fundamentally modern idea of the self. The formation of the prior assumed identity for whom questions of "authenticity" now begin to appear on the horizon is not narrated in the autobiography or theorized in the essays. Unlike many other African autobiographies/Bildungsromane, there is no alienation from an embedded identity, no nostalgia in exile, or, in its other embodiment, ironic distance from the process which transforms the person into the individual which forms the dominant tone of other African life narratives. Questions of identity and authenticity are wholly modern questions. Soyinka's project allows the accretion of an African gloss onto an already modern sense of self, where the idea of "Africa" also is a response to modern colonialism. Nowhere do these contradictions become more apparent than in the incident of the ritual scarification described in Aké, the essential outlines of which are foreshadowed in the adventure where the boy follows the police band to Ibara.

In order to understand the role of ritual scarification in Aké and in Soyinka's reflection on his formation as artist, one needs to understand the significance of scarification among the Yoruba more generally. Henry J ohn Drewal traces the mythological origin of the significance of body marking among the Yoruba to the proverb attested to the god, Olorun, bidding the human being: "open your hand, here are lines" (244). The lines on the palms of the hands are then further elaborated on other parts of the body in the patterns inscribed through scarification and cicatrisation. Among the Yoruba, scarification has a wide range of significances and meanings. Drewal observes that: "Some marks localize a person in time and space, indicating indelibly an individual's place and condition in a broad cultural and ontological system" (244). Scarification sometimes indicates "conditions of birth" as with àbíkú children who die and return to plague their mothers. Some body markings "indicate the presence of younger siblings or relations" (244). The practice of sympathetic scarification also exists where relatives of young people about to undergo circumcision and cicatrization are marked themselves to "remind them to handle the child gently" (1997: 244). Body markings are considered sexually attractive and sometimes are regarded as constituting new erogenous zones. They are also sometimes an indication of inherited occupation, cult membership or mourning. Scarification also has "curative or protective" associations, being performed as a form of medicine or prophylaxis. Body markings are also a somatic index of strength in the face of pain, highly valued among the Yoruba (1997: 244-247). 
Body markings evoke the god, Ògún, in a number of ways. Drewal notes that the olóòlà or body artist is a devotee and is "an extension and manifestation" (1997: 255) of the god, in the sense that through circumcision, excision, scarification, cicatrisation or tattooing he forms the human being through initiating him/her into the various stations and statuses on the road of life. Drewal suggests that: "[l]ike Ògún, who creates order by transforming the forest into farms and cities, and who tames society by judging disruptive individuals, the olóòlà helps to create order by visibly placing individuals in a larger social and cosmic universe" (1997: 255) [emphasis added]. In other words, the significance of scarification is that it literally and figuratively cuts a passage through the person to open the person up to her/ his place in a broader social network. Initiation among the Yoruba, in keeping with the flexibility which is the hallmark of the culture, is not a rigidly structured ritual and may vary from area to area. There is no fixed age at which initiation is required and often the initiation practice is at the request of the particular young person. Initiation among the Yoruba also does not create new forms of community across the age group initiated at one ceremony. Scarification literally and metaphorically opens the person up to a cosmic network, encompassing zones of reality inconceivable to procedural rationality.

Curiously, the role of scarification in Aké cannot be determined with any specificity since it does not appear to form part of an identifiable collective practice. Ritual scarification appears in some ways to be associated with the rites of passage. Its symbolic meaning is not completely clear since it comes upon the boy hero unexpectedly and its potential significance is only elliptically determined from the general context of its performance. The scarification is undertaken by Soyinka's paternal grandfather at his country estate at İsarà where "Essay" and his family visit every Christmas. İsarà is represented in the narrative, in counterpoint to the colonial Christianity of Aké, as pagan, worshipping the gods of the Yoruba fathers. Indeed, in the sequence leading up to the scarification, mention is made for the first time by the grandfather of the deity, Ògún. As has been noted above, in Soyinka's theoretical reflections on his art, Ògún comes to embody the "willful" boundary breaking artist, communicant in his individuality. The child explains to the grandfather how the advice of a neighbour fortuitously saves him from an attack by bees. The grandfather does not regard the incident as coincidental at all. He suggests instead that Wole is under the protection of a divinity: "Ògún protects his own"(1981: 140), the old man proposes. The fact that Soyinka has been shaped by a worldview which is not the worldview enabled by Yoruba mythology is attested by the first person narrator's lack of familiarity with the deity Ògún. The young Wole remarks that he "had heard that name before" (1981: 140). He knows only that Ògún is the name of a pagan devil. The significance of Ògún to Soyinka's metaphysics and aesthetic is a retrospective reinvention.

What is interesting about the representation of the rite of passage incident in Aké, if that indeed is what it is, is that it occurs entirely without social context. The grandfather engages in a coded conversation with the child about schoolyard bullying and his forthcoming relocation at the age of nine-and-a-half to Government College, Ibadan, where he will be parentless, "sharing desks with MEN, not boys!" (1981: 143). He then summons the child to sleep at his house. Shortly before daybreak, the child is unexpectedly woken and the rite is 
performed by an elderly man with his assistant. It involves slashing an "arc of incisions" (1981: 146) on both ankles and both wrists. The grandfather warns the child not to cry out despite the pain. The child is evidently a stranger to the techniques of the procedure about to be performed, as well as its significance to personal and corporate existence. It is rather surprising to learn later, since scarification is a permanent and highly visible mark of incorporation, that he is not certain whether his father underwent the rite. In the context one thus assumes that the ordeal is an initiation into manhood, an assumption to a certain extent affirmed by its recollection in Ibadan in an incident where the protagonist has been injured by being thrown through a glass door. Since the author figure has endured the physical test of "initiation", his foot may be stitched without anaesthetic but with fortitude. The boy hero does not cry in pain (1994: 134-135). This conclusion is challenged however by a parallel reading where it appears that the rite may provide ritual protection against poisoning. The grandfather pointedly tells the child after the operation that he will be able instinctively to intuit whether food offered him is good or tainted.

What distinguishes this initiation, if initiation is what it is, from rite of passage ceremonies generally is the absence of social framing of the experience. Initiation is "one of the most widely distributed human customs," (Bettelheim, 1962: 15) which Arnold Van Gennep, Victor Turner, and J oseph Campbell among others argue acquires its social-symbolic function in the initiate's collectively acknowledged departure from the community, initiation into tribal law (often ineradicably inscribed through mutilation), and return, marked with new status, to the fold of the community. This voyage of self-discovery is dictated by a social code. The acquisition of both experience and new status are enabled and determined by an acknowledged practice which recedes into time immemorial. The initiate rejoins the social world charged with new responsibilities and rights which derive from the social code. Often the rite of passage creates new horizontal communities by age group. Mutilation, whether by tattooing, scarification, circumcision or subincision, is the visible index of transformed social role or status. While the Yoruba do not share all of the elements of the practices of initiation present in other cultures, what is common is the idea of some form of rite of passage determined by a social code.

What is unusual about Aké, unlike virtually every other African autobiography where initiation is described, is the fact that the reader is unable to determine with any degree of specificity the social significance of the rite. The child's experience exists almost as a series of images among the range of other experiences out of which he makes sense of his world. The rite is disembedded from the practices within which it acquires its social significance and becomes in the process a uniquely personal experience in the life journey of the disengaged subject. It is no longer a rite ordained since time immemorial through which the self is socially realized, since the self which is scripted in the autobiography/Bildungsroman is a self which apparently submits to no order outside of a personally constructed order. The young Wole does not submit to Yoruba custom. He does not prostrate himself as required by Yoruba etiquette when greeting elders. He proclaims to a visiting chief: “If I don't prostrate myself to God, why should I prostrate to you?" (1981: 128) 
Scarification in Aké does not, however, represent the alternative lifestyle of "modern primitivism" which paradoxically in its challenge to the commodification of late-capitalist, post-industrialized society itself has become commodified. "Primitive" body modification, tattooing, scarification and other body art, is fashionable. Modern primitivism is a utopian liberatory project which challenges the deindividualization generated by Enlightenment separation of the poetic and scientific through the hyperindividualization promised by "primitive" body modification practices. Body modification in Aké plays a different role. By deftly occluding the Yoruba social code within which the scarification ritual originates and acquires significance and transforming it into the life experience of its autonomous hero, Aké is able to present the "universal verity" of modern identity emerging out of African soil.

But the narrative ironically also exposes the deindividualization which follows the process of individualization which Soyinka presents as authentically African and liberatory. There is a pessimism in the narrating voice of the adult Soyinka returning to his childhood haunts to find them submitting to a commodifying global order. Opposed to the located individualism traced in the autobiography, globalization enforces individual conformity. The narrator points to the conformity created both by commodities and the commodification of art by the culture industry. Rather than the sound of the egungun parade or the police band, Aké is host to "the raucous clang of hand-bells advertising bargain sales of imported wares" (1981: 149) from "a variety of stores peddling the products of a global waste industry" (1981: 149). When the adult narrator returns, the inhabitants of Aké, rather than enjoying the charms of operettas at Centenary Hall, appear to have succumbed to Hollywood: photo-frames now carry the "white voluptuous bodies" of "Raquel Welch, Marilyn Monroe, Diana Dors, Jane Russell" and "Greta Garbo" (1981: 149). Global homogeneity unfortunately is the product of the same modernity for which Soyinka finds autochthonous African roots.

But to return to the question of the scarification in Aké. The scarification thus is symbolic of the formation of a modern, disengaged African individual who, unlike the subject of Cartesian modernity, is unbound and open to the spirit which resides in material reality. What Soyinka forges is the individual who is "disembedded" but not "disenchanted". This may be contrasted with another attempt to write the African subject into modernity. Richard Wright's autobiography, dealing with his travels in the Gold Coast in the mid 1950s, concludes with some revulsion at the "rituals", "mystery, magic" and "witchcraft" he encounters. He suggests that what the African subject must develop, in contrast to Soyinka's disengaged but unbounded self, is a boundedness:

I found only one intangible but vitally important element in the heritage of tribal culture that militated against cohesiveness of action: African culture has not developed the personalities of the people to a degree that their egos are stout, hard, sharply defined; there is too much cloudiness in the African's mentality, a kind of sodden vagueness that makes for lack of confidence, an absence of focus that renders that mentality incapable of grasping the workaday world. And until confidence is established at the center of African personality, until there is an inner reorganization of that personality, there can be no question of marching from the tribal order to the twentieth century. (2008: 410) 
Clearly thus for Wright as opposed to Soyinka, the modern African individual is an individual who must be both "disembedded" and "disenchanted".

Furthermore, for Soyinka, the modern African self must remain connected to other selves thus conceived. This dimension of the subject emerges most clearly in the context of the forced introspection engendered by the solitary confinement imposed by the Gowon regime explored in The Man Died (Prison Notes). Here, Soyinka suggests that "[a]ny faith that places the conscious quest for the inner self as goal, for which the context of forces are mere battle aids is ultimately destructive of the social potential of that self" (1972: 87) [emphasis added]. Thus, self-realization is not achieved when "inner self" reflexively becomes its own fulfillment. Soyinka suggests instead that "inner self" should be kept only as a source of "strength" and "vision": "inner self" should remain only "an unconscious beneficiary from experience" (1972: 87), but the ultimate goal is the connection of the morally autonomous self to other morally autonomous selves.

The significance of the scarification in Ake is that it is the symbolic moment in the autobiography which points to the need for the self to be unbound in Soyinka's conception of the individual. In other words, the subject needs to be opened up to the material and spiritual worlds in a way constitutively denied by procedural rationality. The self for Soyinka must be connected with the world and with other zones of reality. This idea is vital since it forms part of the worldview of all of the cultures of continental Africa. What emerges clearly in much of Soyinka's reflections, but most clearly in the excerpt from the prison notes quoted above, is that Soyinka values the "social potential" of the self. This phrase refers to the way in which one subject is inescapably connected with other subjects. In Soyinka's thought it is the idea of the "cosmic will" of the artist who, like Ògún, opens a path which re-establishes the links between subjects. What is suggested here, however, is that it is not "cosmic will" which creates connections. Instead, the person who locates his idea of self-realization in a social code is inherently "structurally" opened up in the way Soyinka desires. But this is an idea to which Soyinka constitutively cannot submit as a consequence of a conception of the self generated out of limitless freedom rather than freedom realized through recognition of necessary constraint. The scarification in Aké literally "unbinds" the body in the slashing of ankles and wrists. For the body to be more profoundly unbound it must submit to the paradoxically liberating bind of a social ideal - a possibility which does not exist within the framework of Soyinka's self-conception. 


\section{References}

Amoko, A. (2009) Autobiography and Bildungsroman in African Literature, In: Irele, A. F. ed. The Cambridge Companion to the African Novel. Cambridge, Cambridge University Press, pp. 195-196.

Appiah, K.A. (1992) In My Father's House: Africa in the Philosophy of Culture. New York \& Oxford: Oxford University Press.

Barber, K. (1991) I Could Speak Until Tomorrow: Oriki, Women and the Past in a Yoruba Town. Washington DC, Smithsonian Institution Press.

Barber, K. (1994) Polyvocality and the Individual Talent: Three Women Oriki Singers in Okuku. In: Abiodun, R., Drewal, H.J . \& Pemberton, J III. eds. The Yoruba Artist: New Theoretical Perspectives on African Arts. Washington \& London, Smithsonian Institution Press, pp. 151-160.

Bettleheim, B. (1962) Symbolic Wounds: Puberty Rites and The Envious Male. New York, Collier Books.

Buckley, J.H. (1974) Season of Youth: The Bildungsroman from Dickens to Golding. Cambridge, MA, Harvard University Press.

Cosentino, D. J. (1997) Repossession: Ògún in Folklore and Literature. In: Barnes, S.T. ed. Africa's Ògún: Old World and New. $2^{\text {nd }}$ ed. Bloomington \& Indianapolis, Indiana University Press, pp. 290-314.

Cross, A.B. (1996) Sounding Out the Silences: Narratives and Absences in African Higher Education. Edinburgh, Centre of African Studies Edinburgh University, Drewal, H. J . (1997) Art or Accident: Yoruba Body Artists and Their Deity Ögún. In: Barnes, S.T. ed. Africa's Ògún: Old World and New. $2^{\text {nd }}$ ed. Bloomington \& Indianapolis, Indiana University Press, pp. 235-262.

Drewal, H.J . \& Mason, J . (1997) Ògún and Body/ Mind Potentiality: Yoruba Scarification and Painting Traditions in Africa and the Americas. In: Barnes, S.T. ed. Africa's Ògún: Old World and New. $2^{\text {nd }}$ ed. Bloomington \& Indianapolis, Indiana University Press, pp. 332-352.

Drewal, M. T. (1994) Embodied Practice/Embodied History: Mastery of Metaphor in the Performances of Diviner Kolawole Ositola. In: Abiodun, R., Drewal, H.J . \& Pemberton, J III. eds. The Yoruba Artist: New Theoretical Perspectives on African Arts. Washington \& London, Smithsonian Institution Press, pp.171-190.

Huddart, D. (2008) Postcolonial Theory and Autobiography. London and New York, Routledge. 
J ahn, J . (1966) A History of Neo-African Literature: Writing in Two Continents. Translated by Oliver Coburn and Ursula Lehrburger. London, Faber and Faber.

Jeyifo, B. (2004) Wole Soyinka: Politics, Poetics and Postcolonialism. Cambridge, Cambridge University Press.

Jones, E.D. (1973) Akè: The Years of Childhood. The Writing of Wole Soyinka. London, J ames Currey \& Portsmouth, N.H., Heinemann, pp. 23-37.

James, O. (1973) Tell me Africa: An Approach to African Literature. Princeton, NJ, Princeton University Press.

Moore-Gilbert, B. (2009) Postcolonial Life-Writing: Culture, politics and self-representation. London and New York, Routledge.

Pascal, R. (1960) Design and Truth in Autobiography. Cambridge, Massachusetts, Harvard University Press.

Pemberton, J . III. (1994) Introduction: In Praise of Artistry. In: Abiodun, R., Drewal, H.J . \& Pemberton, J III. eds. The Yoruba Artist: New Theoretical Perspectives on African Arts. Washington \&London, Smithsonian Institution Press, pp. 119-137.

Quayson, A. (1997) Strategic Transformations in Nigerian Writing: Orality and history in the work of Rev. Samuel J ohnson, Amos Tutuola, Wole Soyinka \& Ben Okri, Oxford, J ames Currey \& Bloomington, Indiana University Press.

Slaughter, J.R. (2006) Enabling Fictions and Novel Subjects: The Bildungsroman and International Human Rights Law. PMLA 121 (5), pp. 1405-1423.

Soyinka, W. (1972) The Man Died: Prison Notes of Wole Soyinka. London, Rex Collings. Soyinka, W. (1976) Myth, Literature and the African World. Cambridge: Cambridge University Press.

Soyinka, W. (1981) Akè: The Years of Childhood, London, Methuen, 1981.

Soyinka, W. (1992) Interview with J ane Wilkinson. Talking With African Writers, London, J ames Currey \& Portsmouth (N.H.), Heinemann, 1992, pp. 90-108.

Soyinka, W. (1993) The Blackman and the Veil: A Century On and Beyond the Berlin Wall. Accra, Sedco Publishing Ltd. \&W.E.B. Du Bois Memorial Centre for Pan African Culture.

Soyinka, W. (1994) Ibadan: The Penkelemes Years A Memoir 1946-1965. London, Methuen.

Soyinka, W. (2002a) Interview with Anthony Appiah, In: J eyifo, B. ed. Conversations with Wole Soyinka. J ackson, University Press of Mississippi, pp. 129-137. 
Wole, S. (2002b) Death and the King's Horseman: A Play, New York, Norton. Soyinka, W. (2007) You Must Set Forth at Dawn: A Memoir. NewYork, Random House. Taylor, C. (1989) Sources of the Self: The Making of the Modern Identity. Cambridge, Cambridge University Press.

Wright, R. (2008) Black Power Three Books from Exile: Black Power; The Colour Curtain; and White Man, Listen! New York, London, Toronto \& Sydney, Harper Collins.

Yai, O.B. (1994) In Praise of Metonymy: The Concepts of "Tradition" and "Creativity" in the Transmission of Yoruba Artistry over Time and Space. In: Abiodun, R., Drewal, H.J . \& Pemberton, J III. eds. The Yoruba Artist: New Theoretical Perspectives on African Arts. Washington \&London, Smithsonian Institution Press, 107-118. 